\title{
Effects of sulindac on sporadic colorectal adenomatous polyps
}

\author{
N Matsuhashi, A Nakajima, Y Fukushima, Y Yazaki, T Oka
}

\begin{abstract}
Background-Although sulindac is known to cause regression of colorectal adenomatous polyps in familial adenomatous polyposis, less is known about the effect of sulindac on sporadic adenomas. The precise mechanisms of these effects also remain to be determined.

Aims-Sulindac was given to patients with sporadic colorectal adenomatous polyps to evaluate its effects on them, and histological analysis was performed to elucidate the mechanism of the polyp regression, as well the kind of adenomatous polys that are susceptible to the agent.
\end{abstract}

Subjects-20 adenomatous polyps in 15 patients were studied.

Methods-Sulindac (300 mg daily) was given for four months, followed by colonoscopy with removal of the residual polyps. Polyp size, degree of atypia, inflammatory cell infiltration in the polyps, and immunostaining for mutant p53 product were evaluated before and after treatment.

Results-13 of the 20 polyps shrank or disappeared. Patient sex, polyp location, size, degree of atypia, or p53 mutation did not affect the response, but polyps in older patients were more sensitive to sulindac. The degree of atypia or inflammatory cell infiltration was not affected by the treatment. A polyp containing a focal cancer was unresponsive.

Conclusions-Sulindac can cause regression of sporadic colorectal adenomatous polyps.

(Gut 1997; 40: 344-349)

Keywords: sulindac, NSAID, sporadic colorectal adenomatous polyp, familial adenomatous polyposis, colorectal cancer.

of Internal Medicine

N Matsuhashi

A Nakajima

Y Fukushima

Y Yazaki

Department of

Pathology

T Oka

Faculty of Medicine, University of Tokyo, Tokyo, Japan

Correspondence to: Dr N Matsuhashi, The Third Department of Internal Medicine, Faculty of Medicine,

University of Tokyo,

7-3-1 Hongo, Bunkyo-ku,

Tokyo, 113 Japan.

Accepted for publication 28 August 1996 significant regression of sporadic colonic polyps. ${ }^{14-16}$ However, no essential differences between adenomatous polyps in FAP anw sporadic polyps are known, both histologicallyand genetically. ${ }^{17}$ Therefore, because sulindacis known to have a regressive effect on FAP polyps, an anti-adenomatous polyp effect of sulindac in sporadic polyps might be expected We studied the treatment of sporadic colorectab polyps with this agent in another population. is

\section{Methods}

\section{Patients}

The patients (11 men age (mean (SD)), 56.9 $(7 \cdot 6)$ years old) were treated at Tokyo $\overrightarrow{0}$ University Hospital. Patients in whom one or? more colorectal polyps were diagnosed by barium enema studies subsequently underwent colonoscopy, and biopsy specimens of the colorectal polyps were obtained. Patientso whose polyps proved to be adenomas on histo-市 logical examination were included in the study No patient had FAP or Lynch syndrome? (hereditary non-polyposis colorectal cancer) that is, all patients had less than 10 polyps and no patient met the criteria for Lynch syn $-\overrightarrow{0}$ drome. ${ }^{18}$ Informed consent was obtained from each patient before treatment. Patients witho severe liver, kidney, or cardiopulmonary. diseases, past histories of gastrointestina tact bleeding, peptic ulcer disease, or long term non-steroidal anti-inflammatory drug (NSAID) use were excluded from the study $\frac{}{0}$ Patients with adenomatous polyps exhibiting severe atypia were excluded from the studyo because prompt polypectomy was required in such cases.

Study design

A total of 20 adenomatous polyps in 15 patient were studied. On colonoscopy, a biopsy specimen was obtained from each polyp, and to evaluate size each polyp was photographed with an open biopsy forceps (FB50Q; Olympus̊ Corp, Tokyo) beside it. The sizes of the polyps were estimated from the photographs. Histo- 0 logical examination was performed by meanso of haematoxylin and eosin staining. Afteto histological examination, each patient waș given $150 \mathrm{mg}$ of sulindac twice a day for four months, a protocol similar to previous studies. ${ }^{3-7}$ 9-11 14-16 Compliance was assessed at monthly interviews. Histological examination was performed by two independent pathologists in a blinded fashion, and the degree of atypia was graded as mild, moderate, or severe 
TABLE I Patient and polyp characteristics and response to sulindac

\begin{tabular}{|c|c|c|c|c|c|c|c|c|c|c|c|}
\hline Patient & $\begin{array}{l}\text { Age, } \\
\text { sex }\end{array}$ & polyp (n) & Site & $\begin{array}{l}\text { Atypia† } \\
\text { before }\end{array}$ & after & $\begin{array}{l}\text { Polyp } \\
\text { before }\end{array}$ & $\begin{array}{l}(\mathrm{mm}) \\
\text { after }\end{array}$ & $\begin{array}{l}\text { Mononuc } \\
\text { before }\end{array}$ & 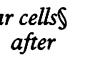 & $\begin{array}{l}\text { p53 st } \\
\text { before }\end{array}$ & ing \\
\hline $\begin{array}{l}\mathrm{G} \\
\mathrm{H} \\
\mathrm{I} \\
\mathrm{J} \\
\mathrm{K} \\
\mathrm{L} \\
\mathrm{M} \\
\mathrm{N} \\
\mathrm{O}\end{array}$ & $\begin{array}{l}63, M \\
54, \mathrm{~F} \\
64, M \\
48, M \\
66, M \\
44, \mathrm{~F} \\
66, \mathrm{~F} \\
59, \mathrm{M} \\
48, M\end{array}$ & $\begin{array}{l}1 \\
1 \\
1 \\
1 \\
1 \\
1 \\
2 \\
3 \\
4 \\
5 \\
6 \\
1 \\
1 \\
1 \\
1 \\
1 \\
1 \\
1 \\
1 \\
1\end{array}$ & $\begin{array}{l}\text { D } \\
\text { S } \\
\text { S } \\
\text { R } \\
\text { S } \\
\text { A } \\
\text { T } \\
\text { D } \\
\text { S } \\
\text { S } \\
\text { S } \\
\text { S } \\
\text { S } \\
\text { T } \\
\text { S } \\
\text { D } \\
\text { R } \\
\text { S } \\
\text { D } \\
\text { R }\end{array}$ & $\begin{array}{l}\text { mil } \\
\text { mod } \\
\text { mil } \\
\text { mil } \\
\text { mod } \\
\text { mod } \\
\text { mil } \\
\text { mil } \\
\text { mod } \\
\text { mod } \\
\text { mod } \\
\text { mod } \\
\text { mod } \\
\text { mil } \\
\text { mil } \\
\text { mod } \\
\text { mil } \\
\text { mod } \\
\text { mod } \\
\text { mil }\end{array}$ & 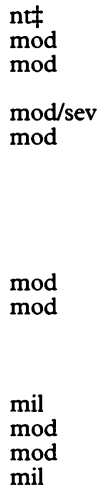 & $\begin{array}{r}13 \\
15 \\
8 \\
5 \\
13 \\
7 \\
4 \\
4 \\
4 \\
8 \\
10 \\
28 \\
10 \\
5 \\
4 \\
4 \\
14 \\
12 \\
15 \\
5\end{array}$ & $\begin{array}{r}3 \\
8 \\
7 \\
0 \\
15 \\
5 \\
0 \\
0 \\
0 \\
0 \\
0 \\
8 \\
12 \\
0 \\
0 \\
0 \\
10 \\
6 \\
12 \\
5\end{array}$ & $\begin{array}{l}36(11) \\
29(2) \\
33(2) \\
23(6) \\
42(11) \\
50(4) \\
51(8) \\
65(7) \\
42(6) \\
43(2) \\
44(5) \\
35(14) \\
55(14) \\
59(11) \\
63(2) \\
46(9) \\
48(7) \\
48(3) \\
44(2) \\
\text { nt }\end{array}$ & $\begin{array}{l}\text { nt } \\
30(6) \\
33(1) \\
33(5) \\
34(3)\end{array}$ & $\begin{array}{l}- \\
- \\
- \\
- \\
- \\
- \\
- \\
- \\
- \\
- \\
\text { nt } \\
\pm \\
\pm \\
+ \\
\pm \\
\pm \\
-\end{array}$ & $\begin{array}{l}\overline{\text { focal }} \\
\pm \\
+ \\
\pm \\
\pm \\
-\end{array}$ \\
\hline
\end{tabular}

^A; ascending, D; descending, S; sigmoid, T; transverse colon, $R$; rectum. tmil; mild atypia, mod; moderate atypia, sev; severe atypia. ‡nt; not tested. $\oint$ Numbers of mononuclear cells counted in high power views. Data shown as mean (SEM).

atypia, with reference to goblet cell depletion, nuclear atypia, and structural disorders. The polyp size was similarly evaluated after four months of sulindac administration. Positive response was defined as a greater than $40 \%$ decrease in polyp diameter. At that time, residual polyps were polypectomised and examined pathologically. Infiltrating mononuclear cell counts were determined by counting such cells within a circle in the visual field visualised in three high power views $(\times 1000)$ of the lamina propria mucosae of the polyps.

Immunohistochemical analysis for mutated p53 product was performed as described ${ }^{19}:$ in brief, $5 \mathrm{~mm}$ thick sections of formalin fixed, paraffin wax embedded tissues were stained using the human p53 specific mouse monoclonal antibody Pab1801 (Oncogene Science, Manhasset, NY). Sections were rehydrated in graded alcohols incubated in normal rabbit serum diluted 1:5 in TRIS buffered saline (145

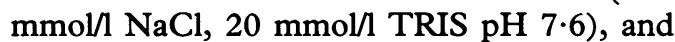
exposed to primary antibody at a dilution of 1:100 for one hour. Bound antibody was detected using biotinylated rabbit antibody to mouse immunoglobulin (Dakopatts No E354, Glostrup, Denmark) and avidin-biotin complex linked to horseradish peroxidase
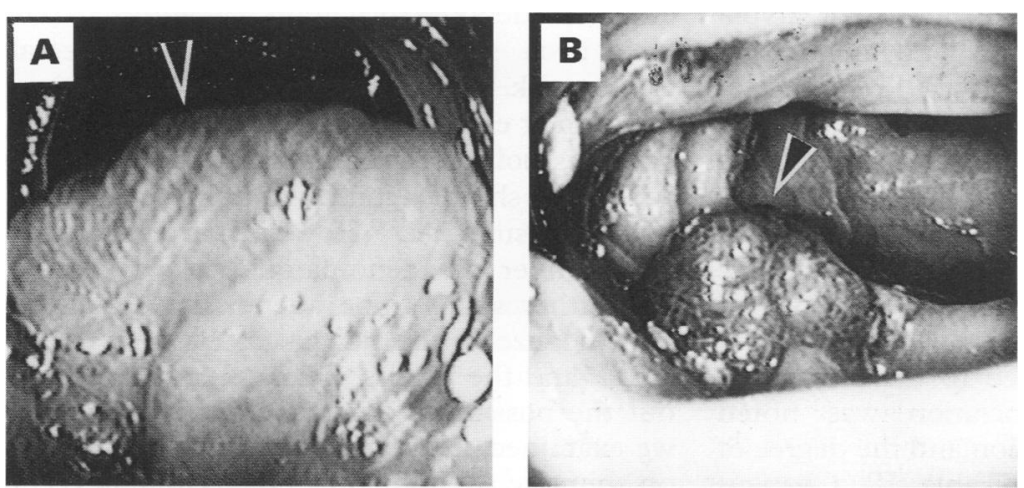

Endoscopic views of a polyp (arrowheads) in a patient (patient $G$ ) before $(A)$ and after $(B)$ sulindac administration. In $(A)$, the polyp was too large to be photographed in one view and the distal side of the polyp cannot be seen. The polyp occupies almost half the area of the colonic lumen. The size was determined with the aid of barium enema films $(28 \mathrm{~mm})$. (B) shows that the polyp size considerably decreased $(8 \mathrm{~mm})$ after sulindac treatment.
(Dakopatts No 335). Staining was with diaminobenzidine $(1 \mathrm{mg} / \mathrm{ml})$ in the presence of $0.03 \%$ hydrogen peroxidase. Endogenous peroxidase was not inhibited. Normal colonic mucosa and a colon cancer tissue known to be positive for mutant p53 were used as negative and positive controls. These controls were included in each run, receiving either primary antibody or simply dilution buffer, to monitor consistency and act as controls. Sections underwent a light haematoxylin counterstain and were dehydrated in graded alcohols and xylene before mounting.

\section{Statistical analysis}

Statistical analyses were performed by Welch $t$ test (patient age, polyp size, and mononuclear cell infiltration) and Fisher's exact probability test (patient sex, polyp location, histological atypia, and p53 staining) and a p value of less than $5 \%$ was taken to indicate significance.

\section{Results}

\section{Response to sulindac}

All patients took more than $80 \%$ of the prescribed drugs. As Table I shows, more than $40 \%$ loss in polyp diameter was observed in 13 of 20 polyps tested. The Figure shows an example of a shrunken polyp. Before treatment (A), the polyp was rather large and occupied amost half the area of the colonic lumen. After sulindac treatment (B), the polyp decreased considerably in size. Moreover, nine of the 13 sulindac sensitive polyps completely disappeared on colonoscopic examinations. Mean

TABLE II Changes of polyp size and number of mononuclear cell infiltration after sulindac treatment

\begin{tabular}{lcll}
\hline & Before & After & \\
\hline $\begin{array}{c}\text { Polyp size (mm) } \\
(\mathrm{n}=20)\end{array}$ & $9 \cdot 4(6 \cdot 0)$ & $4 \cdot 6(5 \cdot 0)^{\star}$ & $\mathrm{p}<0 \cdot 01$ \\
$\begin{array}{c}\text { Mononuclear cell infiltration } \\
(\mathrm{n}=9)\end{array}$ & $43(9)$ & $41(9)$ & NS \\
\hline
\end{tabular}

$\star$ Polyps that disappeared were calculated as $0 \mathrm{~mm}$. Data shown as mean (SEM) 
TABLE III Characteristics of responsive and non-responsive polyps

\begin{tabular}{llll}
\hline & Responsive & Unresponsive & \\
\hline Patient age (mean SD)) & $59 \cdot 8(7 \cdot 5)$ & $52 \cdot 0(5 \cdot 7)$ & p<0.05 \\
Sex (M/F) (mm) (mean (SEM)) & $7 / 1$ & $3 / 3$ & NS \\
Polyp size (mm) & $8 \cdot 9(7 \cdot 0)$ & $10 \cdot 3(3 \cdot 8)$ & NS \\
Site (right/left colon) & $2 / 11$ & $1 / 6$ & NS \\
Atypia (mild/moderate) & $6 / 7$ & $3 / 4$ & NS \\
Mononuclear cell infiltration (mean (SEM)) & $45(13)$ & $46(7)$ & NS \\
p53 staining (+/-) & $3 / 9$ & $2 / 5$ & \\
\hline
\end{tabular}

polyp diameter decreased from $9 \cdot 4 \mathrm{~mm}$ to $4 \cdot 6$ $\mathrm{mm}$ (Table II; $\mathrm{p}<0.01$ ). In a patient with four adenomatous polyps (patient $\mathrm{A}$ ), all polyps decreased or disappeared after sulindac administration, but three of them were excluded from the study, because biopsy samples were not obtained from them before treatment. In another patient with six polyps (patient $F$ ), five of them completely disappeared while one remained unchanged.

The mean ages of patients with responsive and non-responsive polyps were $59 \cdot 8$ and $52 \cdot 0$ years old, respectively (Table III), and patients with responsive polyps were significantly older than those with resistant polyps $(p<0 \cdot 05)$. As Table III shows, polyps in female patients were slightly more resistant to the treatment than male ones, but the difference was not statistically significant $(p=0 \cdot 12)$.

Table I shows that seven of eight polyps with a diameter of $5 \mathrm{~mm}$ or less responded to sulindac, while six of 12 polyps with a diameter of $6 \mathrm{~mm}$ or larger did not. This suggested that small polyps are more sensitive to sulindac. However, the $p$ value for this difference was slightly above the significance level $(p=0 \cdot 08)$. Thus the difference was not statistically significant.

Three polyps were located in the right side colon (ascending and transverse colon) and 17 in the left side (descending and sigmoid colon, and rectum), and response did not differ significantly according to the location of the polyps (Table II).

There was also no significant difference in the mean original diameters of polyps responsive and unresponsive to sulindac treatment ( 8.9 and $10.3 \mathrm{~mm}$, respectively; Table III).

\section{Degree of atypia}

All of the polyps tested were histologically tubular adenomas, but the degree of atypia varied: nine were adenomas with mild atypia and 11 had moderate atypia. Histological examination of the polypectomy specimen after the treatment showed that one of the polyps with moderate atypia contained a tiny focal cancer. That polyp, $13 \mathrm{~mm}$ in original diameter, did not regress after sulindac administration. However, six of nine polyps with mild atypia and seven of 11 polyps with moderate atypia responded to the treatment, and no significant association was noted between the polyp regression and the degree of atypia, mild or moderate (Table III). Changes in atypia were evaluated in the 10 polyps in which histological examination was available both before and after the treatment. In the three sulindac responsive polyps, the atypia did not change after treatment. However, among the seven unresponsive polyps, two showed an increase in the degree of atypia.

\section{Infiltrating cell numbers}

Numbers of infiltrating mononuclear cells in lamina propria mucosae of adenomas slightly decreased after the treatment (mean (SEM)) $\stackrel{\vec{S}}{\rightarrow}$ (before; 43 (9) and after; 41 (9), but the differ- 0 ence was not statistically significant (Table II).

Pre-treatment infiltrating mononuclear cell $\frac{\omega}{7}$ numbers of responsive and unresponsive $\stackrel{\mathbb{\Omega}}{\varrho}$ polyps were 45 (13) and 46 (7), respectively ڤ (Table III), and the infiltrating cell number did $\vec{\circ}$ not have any influence on polyp regressive effect.

\section{p53 Staining}

On immunohistochemical examination for $\dot{\omega}$ mutant p53 product, five were positive and $14 \omega$ were negative at the beginning. Three of five p53 positive polyps and nine of 14 negative ones responded to the treatment, and there was $\vec{z}$ no correlation between p53 positivity and sulindac responsiveness.

\section{Discussion}

Sulindac has attracted much interest because of its suppressive effect on adenomatous polyps in FAP. Anti-neoplastic effects of NSAIDs were reported as early as the $1970 \mathrm{~s} .{ }^{20-27}$ On the $\frac{\circ}{D}$ other hand, indomethacin has been shown to have regressive effects on human desmoid $\frac{0}{3}$ tumours since $1980 .^{28}$ Skin cancers in xero- $\frac{3}{5}$ derma pigmentosum ${ }^{29}$ or cancers of the head and neck $^{30}$ are also known to be responsive to NSAIDs. The first report on a suppressive effect of sulindac on adenomatous polyps in patients with FAP appeared in 1983, in which a patient with FAP treated by sulindac for her $\frac{\delta}{3}$ desmoid tumour showed a pronounced regression of her colorectal polyps. ${ }^{1}$ Thereafter, 을 experience with FAP polyp regression by sulin- $\frac{D}{O}$ dac has accumulated..$^{2-11}$ Duodenal polyps in FAP patients also respond to sulindac. ${ }^{31} \mathrm{~N}$ Indomethacin suppositories have been re- $N$ ported to cause regression of rectal polyps in N FAP, as well. ${ }^{1012} 13$ Another line of studies has $\frac{\omega}{\sigma}$ suggested that NSAIDs have a preventive effect on adenoma formation, ${ }^{32-34}$ and NSAIDs $\frac{0}{0}$ have been suggested to decrease colorectal $\stackrel{\oplus}{\rightarrow}$ cancer risk. ${ }^{35-37}$ In contrast, little is known to about their effects on sporadic colorectal adenomatous polyps. A recent study, for example, $\stackrel{D}{\square}$ failed to show significant polyp regressive $\stackrel{\mathbb{Q}}{\Omega}$ effects of sulindac. ${ }^{14}$ However, in that study, $\bar{O}$ the number of adenomatous polyps studied $ᄋ$ was rather small (nine adenomatous polyps) 음 and the size of the polyps tested were rather small, and the results did not completely rule out the possibility of such effects. Therefore, we examined the regressive effects of sulindac on sporadic adenomatous polyps in a different population along with histological evaluation of the treated polyps.

As described above, subsequent to treatment, 13 of 20 polyps tested had a greater than 
$40 \%$ loss in polyp diameter. Remarkably, nine of 13 polyps had completely disappeared on colonoscopic examination. These results show that sulindac has a regressive effect on sporadic adenomatous polyps, at least in some patients.

Certain hypotheses on the mechanism of polyp regression by sulindac have been postulated, ${ }^{15}$ 38-41 but the precise mechanism of action is not yet known. As a polyp consists of adenoma cells and interstitial components such as infiltrating cells or connective tissues, or both, reduction in polyp size would have to be the result of a decrease in either or both of these components. Therefore, a possibility that a reduction in components other than adenoma cells, such as inflammatory cells, contributes to polyp shrinkage, has not been ruled out. This is especially noteworthy in light of the fact that sulindac is an anti-inflammatory drug. Therefore, histological changes induced by the treatment were investigated. However, no significant changes in inflammatory cell numbers could be detected. Therefore, it seems that the cause of decrease in polyp size was not inflammatory cell depletion. On the other hand, the interstitial tissues of the polyps (oedema, fibrous tissues, or haemorrhage) did not change significantly either (data not shown). Therefore, polyp regression is histologically suggested to be due to adenoma cell depletion. Histological examination failed to show any decrease in the degree of atypia in sulindac treated polyps. This implies that the anti-polyp effect was not associated with induction of differentiation.

It is possible, of course, that a certain subpopulation of polyps or polyps at a certain stage $^{17}$ are susceptible to the drug. In this regard, we have investigated predisposing factors including patient age and sex, polyp location, degree of atypia, polyp size, mononuclear cell infiltration into lamina propria mucosae, and mutant p53 product via immunostaining, in relation to the responses to treatment (Table III). As described above, patient sex did not affect the responses, but polyps in older patients were more responsive to sulindac. Analyses of response to sulindac in relation to patient ages will be of relevance.

Macroscopically, the location or size of the polyps did not significantly affect the sensitivity. However, it has been reported that small duodenal polyps, $2 \mathrm{~mm}$ or less in size, are sensitive to sulindac in FAP patients. ${ }^{42}$ In this study polyps of $5 \mathrm{~mm}$ or less showed a higher response rate (seven of eight) than larger polyps (six of 12), although the difference was not statistically significant. However, this result does not rule out a possibility that tiny polyps (for example, $2 \mathrm{~mm}$ or less) are more sensitive to sulindac. Further detailed studies are necessary to elucidate this issue.

Concerning the degree of atypia, there was no statistically significant difference in responses between adenomas with mild atypia and moderate atypia, and both types of adenomas responded to the treatment. None of the polyps were judged to be adenomas with severe atypia before treatment, but in this study, the only polyp that proved to contain a tiny focal cancer at the end of the treatment, did not respond to the treatment. Established cancers may not be sensitive to the drug. No significant difference in mononuclear cell infiltration was noted in relation to responsiveness to sulindac.

Little is known about the effects of sulindac on cancer related gene products, but an abstract reports that sulindac reduces the levels of mutant $\mathrm{p} 53 .^{43}$ This change may be related to anti-neoplastic properties of the drug. Mutated p53 product was examined by immunohistochemical staining in this study to see whether changes in $\mathrm{p} 53$ expression is taking place in the treatment course, and whether p 53 mutation is a predisposing factor for response to sulindac. However, it was hard to evaluate changes in mutant p53 levels induced by sulindac, because only three polyps were positive for $\mathrm{p} 53$ before the treatment. Both p53 positive and negative polyps responded to the drug. However, as positive staining in a colorectal adenoma is often focal, ${ }^{44}$ as seen in several polyps tested in this study (data not shown), and specimens stored at room temperature for months may lose immunoreactivity to antip53 antibodies, ${ }^{45}$ further investigations are necessary to elucidate the role of p53 in the sulindac induced polyp regression. Thus, the results of $\mathrm{p} 53$ analysis in this study were inconclusive and the possibility of a p53 gene alteration in sulindac induced adenoma regression cannot be ruled out.

Regression of colorectal adenomas would be of especially great benefit if such polyp regression could really lead to cancer prevention. Animal experiments ${ }^{46-55}$ as well as epidemiological studies ${ }^{33-37}$ suggest that NSAIDs do have a colorectal cancer preventive effect, but on the other hand, rectal cancers are reported to occur in FAP patients treated with sulindac. ${ }^{56}$ In this regard, it is noteworthy that an adenomatous polyp containing a focal cancer did not respond to sulindac, and that some of non-reponsive polyps exhibited increases in atypia after sulindac therapy in this study. The degree of atypia before treatment did not affect response to sulindac in this study, but it should be noted that adenomas with severe atypia were excluded. The effect of sulindac on adenomas with severe atypia remains to be elucidated, and longer observation of FAP patients treated wih sulindac is necessary.

Irrespective of the cancer preventive effect, medical reduction of colorectal polyp size by sulindac should be of benefit in reducing risks associated with polypectomy procedures. Large polyps are generally associated with higher risks of complications such as bleeding or intestinal perforation. Indeed, in this study, a polyp originally $28 \mathrm{~mm}$ in size in a patient could be resected very easily, because the polyp diameter decreased dramatically to $8 \mathrm{~mm}$ (patient G). Thus, sulindac may prove to be the drug of choice in mass reduction of adenomatous polyps prior to endoscopic polypectomy, especially in large polyps.

The optimal dose of sulindac in colorectal adenoma treatment remains to be determined. 
For example, the dose of aspirin required for inhibition of platelet aggregation is known to be much lower than that for analgesic or antipyretic use. We administered $300 \mathrm{mg}$ of sulindac per day, a common dose when used as an anti-inflammatory or analgesic drug, but epidemiological studies show that low doses of NSAIDs seem to be effective in colorectal cancer prevention. ${ }^{32-36}$ The dose of sulindac required for adenomatous polyp regression may be lower than that adopted in this and previous studies. In fact, a recent study reported a rectal polyp regressive effect with a low dose sulindac suppository (about $50 \mathrm{mg}$ daily). ${ }^{12}$ Further investigation is required to resolve this issue.

We are grateful to Professor J Patrick Barron, Tokyo Medica College, for critical review of the manuscript. A part of thi study was published as an abstract in Digestive Diseases Week, 1996

1 Waddell WR, Loughry RW. Sulindac for polyposis of the colon. F Surg Oncol 1983; 24: 83-7.

2 Gonzaga RAF, Lima FR, Carneiro S, Maciel J Amarante Jr M. Sulindac treatment for familial polyposis Amarante Jr M. Sulindac

3 Waddell WR, Ganser GF, Cerise EJ, Loughry RW. Sulindac polyposis of the colon. Am F Surg 1989; 157: 175-9.

4 Friend $W$. Sulindac suppression of colorectal polyps in Gardner's syndrome. Am Fam Phys 1990; 41: 891-4.

5 Charneau J, D'Aubigny N, Burtin P, Person B, Boyer J. Micropolypes rectaux apres colectomie totale pour polypose familiale: efficacite du sulindac. Gastroenterol Clin Biol 1990; 14: 153-7.

6 Labayle D, Fischre D, Vielh P, Drouhin F, Pariente A Bories C, et al. Sulindac causes regression of rectal polyps in familial adenomatous polyposis. Gastroenterology 1991 , 101: 635-9.

7 Rigau J, Pique JM, Rubio E, Planas R, Tarrech JM, Bordas JM. Effect of long-term sulindac therapy on colonic polyposis. Ann Intern Med 1991; 115: 952-4

8 Giardiello FM, Hamilton SR, Krush AJ, Hylind LM Celano P, Booker SV, et al. Treatment of colonic and rectal adenomas with sulindac in familial adenomatous polyposis. N Engl F Med 1993; 328: 1313-6.

9 Nugent KP, Farmer KC, Spigelman AD, Williams CB Phillips RK. Randomized controlled trial of the effect of sulindac on duodenal and rectal polyposis and cell proliferation in patients with familial adenomatous polyposis. liferation in patients with fam

10 Winde G, Gumbinger HG, Osswald H, Kemper F, Bunte H. The NSAID sulindac reverses rectal adenomas in colectomized patients with familial adenomatous polyposis: clinical results of a dose-finding study on rectal sulindac administration. Int $\mathcal{F}$ Colorectal Dis 1993; 8: 13-7.

11 Spagnesi MT, Tonelli F, Dolara P, Caderni G, Valanzano R, Anastasi A, et al. Rectal proliferation and polyp occurrence in patients with familial adenomatous polyposis rence in patients with familial adenomatous polyposis 362-6.

12 Winde G, Scmid KW, Schlegel W, Fischer R, Osswald H, Bunte $H$. Complete reversion and prevention of recta adenomas in colectomized patients with familial adenomatous polyposis by rectal low-dose sulindac maintenance treatment. Dis Colon Rectum 1995; 38: 813-30.

13 Hiraka K, Itoh H, Ohsato K. Regression of rectal polyps by indomethacin suppository in familial adenomatous polyposis. Dis Colon Rectum 1994; 37: 943-6.

14 Hixson LJ, Earnest DL, Fennerty MB, Sampliner RE. NSAIDs effect on sporadic colon polyps. Am $\mathcal{F}$ Gastroenterol 1993; 88: 1652-6.

15 Ladenheim J, Garcia G, Titzer D, Herzenberg H, Lavori $P$ Edson $R$, et al. Effect of sulindac on sporadic colonic polyps. Gastroenterology 1995; 108: 1083-7.

16 DuBois RN. Nonsteroidal anti-inflammatory drug use and sporadic colorectal adenomas. Gastroenterology 1995; 108 . $1310-4$

17 Fearon ER, Vogelstein B. A genetic model for colorectal tumorigenesis. Cell 1990; 61: 759-67.

18 Vasen HFA, Mecklin JP, Khan PM, Lynch HT. Hereditary non-polyposis colorectal cancer. Lancet 1991; 338: 877.

19 Purdie CA, O'Grady J, Piris J, Wyllie AH, Bird CC. p53 expression in colorectal tumors. Am $\mathcal{F}$ Pathol 1991; 138 807-13.

20 Powles TJ, Clark SA, Easty DM, Easty GC, Neville AM The inhibition by aspirin and indomethacin of osteolytic tumor deposits and hypercalcemia in rats with Walker tumor deposits and hypercalcemia in rats with Walker tumour and is possible application

21 Humes JL, Strausseer HR. Prostaglandins and cyclic nucleotides in Moloney sarcoma tumors. Prostaglandin $1974 ; 5$ : 183-96.

22 Strausser HR, Humes JL. Prostaglandin synthesis inhibition: effect on bone changes and sarcoma tumo induction in BALB/c mice. Cancer 1975; 15: 724-30.
23 Hial V, Horakova Z, Shaff RE, Beaven MA. Alteration of tumor growth by aspirin and indomethacin: studies with two transplantable tumors in mouse. Eur $\mathcal{f}$ Pharmacol 1976; 37: 367-76.

24 Hial V, De Mello MC, Schaff RE, Horakova Z, Beaven MA. Anti-proliferative activity of anti-inflammatory drugs in two mammalian cell culture lines. F Pharmacol Exp Ther 1977; 202: 446-54.

25 Lynch NR, Castes M, Astoin M, Salomon JC. Mechanism of inhibition of tumor growth by aspirin and indomethacin. Br f Cancer Inst 1979; 62: 117-21.

26 Lynch NR, Salomon JC. Tumor growth inhibition and potentiation of immunotherapy by indomethacin in mice. 7 Natl Cancer Inst 1979; 62: 117-21.

27 Bennett A, Houghton J, Leaper DJ, Stanford IF. Cancer $\bar{C}$ growth, response to treatment and survival time in mice: $\bar{\sigma}$ beneficial effect of the prostaglandin synthesis inhibitor $\overline{\bar{N}}$ flurbiprofen. Prostaglandins 1979; 17: 179-91.

28 Waddell WR, Gerner RE. Indomethacin and ascorbate $\mathbb{\Phi}$ inhibit desmoid tumors. F Surg Oncol 1980; 15: 85-90.

29 Al Saleem T, Ali ZS, Qassab M. Skin cancers in xeroderma pigmentosum: response to indomethacin and steroids. $\overrightarrow{0}$ Pignct 1980; ii: 264-5.

30 Panje WR. Regression of head and neck carcinoma with a prostaglandin-synthesis inhibitor. Arch Otolaryngol 1981; $\vec{\omega}$
107: 658-63.

31 Parker AL, Kadakia SC, Maccini DM, Cassaday MA, پิ Angueira CE. Disappearance of polyps in Gardner's syndrome with sulindac therapy. Am $\mathcal{F}$ Gastroenterol 1993; 88: $93-4$.

32 Greenberg ER, Baron JA, Freeman DH, Mandel JS, Haile $\omega$ $R$. Reduced risk of large bowel adenomas among aspirin $\omega$ users. ₹ Natl Cancer Inst 1993; 85: 912-6.

33 Logan RFA, Little J, Hawtin PG, Hardcastle JD. Effect of aspirin and non-steroidal anti-inflammatory drugs on $\mathrm{O}$ colorectal adenomas: case-control study of subjects colorectal adenomas: case-control study of subjects participating in the Nottingham faecal occult blood $\checkmark$ screening programme. BMF 1993; 307: 285-9.

34 Giovannucci E, Rimm EB, Stampfer MJ, Colditz GA, ฏ Ascherio A, Willett WC. Aspirin use and the risk of $\frac{\rho}{\supset}$ colorectal cancer and adenoma in male health professionals. Ann Intern Med 1994; 121: 241-6.

35 Kune GA, Kune S, Watson LF. Colorectal cancer risk, chronic illness, operations, and medications: case control. results from the Melbourne Colorectal Cancer Study. results from the Melbourne Colo

36 Rosenberg L, Palmer JR, Zauber AG, Warshauer ME, Stolley PD, Shapiro S. A hypothesis: nonsteroidal antiinflammatory drugs reduce the incidence of large-bowel cancer. F Natl Cancer Inst 1991; 85: 355-8.

37 Thun MJ, Namboodiri MM, Heath CW. Aspirin use and $\mathbb{D}$ reduced risk of fatal colon cancer. $N$ Engl F Med 1991; 325: 1593-6.

38 Waddell WR. The effect of sulindac on colon polyps: $\frac{\text { 을 }}{3}$ circumvention of a transformed phenotype-a hypothesis.

J Surg Oncol 1994; 55: 52-5.
39 Shiff SJ, Oiao L, Tsai L, Rigas B. Sulindac sulfide, an aspirin-like compound, inhibits proliferation, causes cell cycle quiescence, and induces apoptosis in HT-29 colon adenocarcinoma cells. F Clin Invest 1995; 96: 491-503.

40 Waddell WR, Miesfeld RL. Adenomatous polyposis coli, protein kinases, protein tyrosine phosphatase: the effect of sulindac. ₹ Surg Oncol 1995; 58: 252-6.

41 Pasricha PJ, Bedi A, O'Connor K, Rashid A, Akhtar AJ, Zahurak ML, et al. The effects of sulindac on colorectal $O$ proliferation and apoptosis in familial adenomatous polyposis. Gastroenterology 1995; 109: 994-8.

42 Debinski HS, Trojan J, Nugent KP, Spigelman AD, Phillips RKS. Effect of sulindac on small polyps in familial Phillips RKS. Effect of sulindac on small polyps in familial

43 Goldberg Y, Dynlacht BD, Rigas B, Shiff SJ. Sulindac and $\mathscr{S}$ sulindac sulfide alter the levels of $\mathrm{pRb}$ and $\mathrm{p} 53$ and the $N$ cyclin dependent kinase inhibitor p21 in HT-29 colon cancer cells. Gastroenterology 1995; 108: A475.

44 Yukawa M, Fujimori T, Maeda S, Tabuchi M, Nagasako K. Comparative clinicopathological and immunohistochemical study of ras and p53 in flat and polypoid typece colorectal tumours. Gut 1994; 35: 1258-61.

45 Prioleau JP, Schnitt SJ. p53 antigen loss in stored paraffin $\overparen{D}$ slides. N Engl f Med 1995; 332: 1521-2.

46 Reddy BS, Maruyama H, Kelloff G. Dose-related inhibition $T$ of colon carcinogenesis by dietary piroxicam, a non- $-\bar{O}$ steroidal antiinflammatory drug, during different stages of $\frac{\vec{D}}{\mathbb{D}}$ rat colon tumor development. Cancer Res 1987; 47:

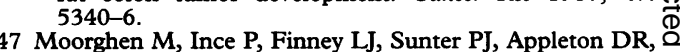
Watson AJ. A protective effect of sulindac against $O$ chemically-induced primary colonic tumours in mice. Pathol 1988; 156: 341-7.

48 Northway MG, Scobey MW, Gassidy KT, Geisinger KR. Piroxicam decreases post irradiation colonic neoplasia in the rat. Cancer 1990; 66: 2300-5.

49 Reddy BS, Nayini J, Tokumo K, Rigotty J, Zang E, Kelloff G. Chemoprevention of colon carcinogenesis by concurrent administration of piroxicam, a nonsteroidal antiinflammatory drug with D,L-alpha-difluoromethylornithine, an ornithine decarboxylase inhibitor, in diet. Cancer Res 1990; 50: 2562-8.

50 Rao CV, Tokumo K, Rigotty J, Zang E, Kelloff G, Reddy BS. Chemoprevention of colon carcinogenesis by dietary administration of piroxicam, alpha- difluoromethylornithine, 16 alpha-fluoro-5-androsten-17-one, and ellagic acid individually and in combination. Cancer Res 1991; 51: 4528-34. 
51 Skinner SA, Penney AG, O'Brien PE. Sulindac inhibits the rate of growth and appearance of colon tumors in the rat. Arch Surg 1991; 126: 1094-6.

52 Craven PA, DeRubertis FR. Effects of aspirin on 1,2-dimethylhydrazine-induced colonic carcinogenesis. Carcinogenesis 1992; 13: 541-6.

53 Reddy BS, Tokumo K, Kulkarni N, Aligia C, Kelloff G. Inhibition of colon carcinogenesis by prostaglandin synthesis inhibitors and related compounds. Carcinosynthesis inhibitors and
genesis 1992; 13: 1019-23.

54 Reddy BS, Rao CV, Rivenson A, Kelloff G. Inhibitory effects of aspirin on azoxymethane-induced colon car- cinogenesis in F344 rats. Carcinogenesis 1993; 14: 1493-7.

55 Rao CV, Rivenson A, Simi B, Zang E, Kelloff G, Steele V et al. Chemoprevention of colon carcinogenesis by sulindac, a nonsteroidal anti-inflammatory agent. Cancer Res 1995; 55: 1464-72.

56 Niv Y, Fraser GM. Adenocarcinoma in the rectal segment in familial polyposis coli is not prevented by sulindac therapy. Gastroenterology 1994; 107: 854-7.

57 Lynch HT, Thorson AG, Smyrk T. Rectal cancer after prolonged chemoprevention. Cancer 1995; 75: 